ISSN: 2231-3354

Received on: 05-05-2012

Revised on: 17-05-2012

Accepted on: 29-05-2012

DO: 10.7324/J APS.2012.2733
Prachya Onkar, J itendra Banger, Revan Karodi

Department of Pharmacognosy,

Padmashree Dr. D. Y. Patil College of Pharmacy, A kurdi, Pune 411044. India
For Correspondence Mr. Revan S. Karod Pad. Dr. D. Y . Patil College of Pharmacy, Sector 29, Ni gdiPradhi karan, A kurdi,

Pune-411 044, Maharashtra, I ndi a. Contact N o.: +91-9860196088

\section{Evaluation of Antioxidant activity of traditional formulation Giloy satva and hydroalcoholic extract of the Curculigo orchioides gaatn}

\author{
Pradnya Onkar, J itendra Bangar and Revan Karod
}

\begin{abstract}
Herbal plants produce a diverse range of bioactive molecules, making them a rich source of different types of medicines. Thus, a proper scientific evidence or assessment has become the criteria for acceptance of herbal health claims. In the present study, the antioxidant effect of the traditional Ayurvedic formulation Giloy Satva (Tinospora cordifolia linn. known as Guduchi) and hydro alcoholic extract of the plant Curculigo orchioides linn. (Kali Musali) were examined. The present study was concentrated on the in vitro antioxidant methods where traditional formulation and hydro alcoholic extract screened for DPPH free radical scavenging activity, total reducing power assay and hydrogen peroxide scavenging activity assay. The results revealed potent scavenging activity when compared with standard. The plant extracts and formulation further phytochemically screened with thin layer chromatographic analysis indicating presence of flavonoids, alkaloids, glycosides, saponins and some amount of phytosterols. These active constituents alone or in combination may be responsible for the observed antioxidant activity. The findings indicated promising antioxidant activity of crude extracts needs further exploration for their effective use in both modern and traditional system of medicines.
\end{abstract}

Keywords: Antioxidant Activity, DPPH, $\mathrm{H}_{2} \mathrm{O}_{2}$ Assay, Reducing Power Assay.

\section{INDUSTRIAL RELEVANCE}

Giloy Satva (Tinospora cordifolia linn. of family Menispermaceae) and Curculigo orchioides gaertn. (family Amarylladaceae) are potent antioxidants found in ayurveda also reported in Rasayana. Tinospora cordifolia is one of the constituents of several ayurvedic preparations used in general debility, dyspepsia, fever and urinary diseases. The extract of its stem is useful in skin diseases. A bark of T. cordifolia has anti-spasmodic, anti-pyretic, anti-allergic, anti-inflammatory and anti-leprotic properties. It is an important ingredient of many Ayurvedic preparations and is considered to have aphrodisiac, immunostimulant, hepatoprotective, antioxidant, anticancer and antidiabetic activities. Hence present study explores the antioxidant activity of the plant extract of Curculigo orchioides gaertn. and traditional formulation.

\section{INTRODUCTION}

Oxygen is essential for the survival of all on this earth. During the process of oxygen utilization in normal physiological and metabolic processes approximately $5 \%$ of oxygen gets univalently reduced to oxygen derived free radicals like superoxide, hydrogen peroxide, hydroxyl and nitric oxide radicals. 
All these radicals known as reactive oxygen species (ROS) exert oxidative stress towards the cells of human body rendering each cell to face out 10000 oxidative hits per second. when generation of ROS overtakes the antioxidant defense of the cell, the free radicals start attacking the cell proteins, lipids and carbohydrates and this leads to a number of physiological disorders. Free radicals are involved in the development of degenerative diseases, they have also been implicated in the pathogenesis of diabetes, liver damage, nephrotoxicity, inflammation, cancer, cardiovascular disorders, neurological disorders, and in the process of aging. Many plant often contain substantial amounts of antioxidants including vitamin $\mathrm{C}$ and $\mathrm{E}$, carotenoids, flavonoids and tannis etc., and thus can be utilized to scavenge the excess free radicals from human body.

In this research work the main objective is to study the antioxidant activity of traditional formulation Giloy satva and hydroalcoholic extract of Curculigo orchioides gaertn.

\section{Antioxidants}

The process of oxidation in the human body damages cell membranes and other structures including cellular proteins, lipids and DNA. When oxygen is metabolised, it creates 'free radicals' which steal electrons from other molecules, causing damage. The body can cope with some free radicals and needs them to function effectively. However, an overload of free radicals has been linked to certain diseases, including heart disease, liver disease and some cancers.

Giloy Satva (Tinospora cordifolia linn. of family Menispermaceae) and Curculigo orchioides gaertn. (family Amarylladaceae) is an endangered rasayana herb which is popularly known as "Guduchi" and "Kali Musli" respectively. The plants are native to India, and holds a special position as a potent adaptogen and aphrodisiac in Ayurvedic system of medicine. They are used as aphrodisiac, immunostimulant, antioxidant, anticancer and antidiabetic properties. Curculigo orchioides Gaertn. is a herbaceous tuberous geophilous perennial with rootstock bearing several fleshy lateral roots (rhizomes). The rhizomes of this plant possess medicinal properties and are sweet, cooling, diuretic, aphrodisiac, viriligenic and tonic which can be used against hemorrhoids, leucorrhoea, pruritis, skin diseases, asthma, bronchitis and jaundice etc. It is used extensively in ayurvedic formulations for a wide variety of ailments, specially as a general tonic and as an aphrodisiac. Thus, present study has been directed to investigate the antioxidant activity of Giloy satva and hydroalcoholic extract of Curculigo orchioides gaertn. plant in different in vitro models (Govindrajan, 2005).

\section{MATERIALS AND METHODS}

\section{Plant Collection and Extraction}

The formulation of Giloy Satva collected from market and fresh part of the Curculigo Orchioides gaertn. were authentified from university of Pune. The powder of rhizomes was extracted by
Maceration using Hydro alcoholic mixture for 72 hours. This extract was concentrated under vacuum and then subjected to preliminary phytochemical screening.

Screening for the preliminary phytoconstituents. (Khandelwal, 2003)

Ethanol extract was evaluated for presence of various phytoconstituents by performing different qualitative chemical tests.

Screening for Thin Layer Chromatography (Wagner, 2004)

The various solvent systems selected for TLC analysis are listed in the following table

Table. 1: Various solvent system.

\begin{tabular}{|c|c|c|c|c|}
\hline no & Detection & Solvent system & Ratio & $\begin{array}{c}\text { Locating } \\
\text { reagent }\end{array}$ \\
\hline 1 & $\begin{array}{l}\text { Glycoside } \\
\text { s }\end{array}$ & $\begin{array}{l}\text { Ethylacetate: Methanol } \\
\text { Ethanol : Water }\end{array}$ & $81: 11: 4: 8$ & $5 \% \mathrm{KOH}$ \\
\hline 2 & $\begin{array}{l}\text { Flavonoid } \\
\mathrm{s}\end{array}$ & $\begin{array}{l}\text { Chloroform: Acetone :Formic } \\
\text { acid }\end{array}$ & $\begin{array}{l}75: 16.5: 8 \\
5\end{array}$ & $\begin{array}{l}\text { Vanillin- } \\
\text { sulfuric acid }\end{array}$ \\
\hline 3 & Alkaloids & $\begin{array}{l}\text { Tolune:ethyl } \\
\text { acetate:diethylamine }\end{array}$ & $70: 20: 10$ & $\begin{array}{l}\text { Dragendroff } \\
\text { 's reagent }\end{array}$ \\
\hline
\end{tabular}

Screening for in-vitro Antioxidant models (Jayaprakash et al, 2001).

The following models are performed for antioxidant activity

DPPH Assay (1, 1 diphenyl 2, picryl hydrazyl) (Vani et al., Sanchez-Moreno, 1999., Navarro et al., 1993): $0.3 \mathrm{ml}$ solution of DPPH in $100 \%$ ethanol was prepared.5 $\mathrm{ml}$ of this solution $+1 \mathrm{ml}$ of the fraction dissolved in ethanol at different concentrations (50$250 \mu \mathrm{g} / \mathrm{ml}$ ), mixture was shaken and allowed to stand at room temperature for $30 \mathrm{~min}$ Absorbance was measured at $517 \mathrm{~nm}$ using a spectrophotometer. The $\%$ scavenging activity at different concentrations was determined and compared with that of Butylated hydroxy toluene, which was used as the standard.

Determination of reducing power. (Jayaprakash et al., 2001): 2.5 $\mathrm{ml}$ of solution of different concentrations of extract $(50,100,150$, 200, $250 \mu \mathrm{g} / \mathrm{ml}$ ). 2.5ml $\mathrm{PO}_{4}$ buffer solution ( $\mathrm{pH}$ 6.6). $2.5 \mathrm{ml}$ potassium ferricyanide solution $(1 \% \mathrm{w} / \mathrm{v})$. Mixture placed in water bath/Incubate at $50^{\circ} \mathrm{C}$ for $20 \mathrm{~min}$. After incubation resulting solution cooled \& mixed with $2.5 \mathrm{ml} 10 \%$ Trichloro acetic acid to each test tube. The mixture was centrifuged at $650 \mathrm{rpm}$ for 10 $\min .2 .5 \mathrm{ml}$ upper solution layer was mixed with $5 \mathrm{ml}$ of deionised water \& $0.5 \mathrm{ml}$ ferric chloride $(1 \% \mathrm{w} / \mathrm{v})$. Absorbance was measured at $700 \mathrm{~nm}$.

Hydrogen peroxide scavenging activity: Hydrogen peroxide $2 \mathrm{~mm} / \mathrm{L}$ solution prepared with standard $\left(\mathrm{PO}_{4}\right.$ buffer $\mathrm{pH}$ 7.4).Different concentrations of extract (50, 100, 150, 200, 250 $\mu \mathrm{g} / \mathrm{ml}$ ) prepared in distilled water. $1 \mathrm{ml}$ of solution of different concentrations of extract $(50,100,150,200,250 \mu \mathrm{g} / \mathrm{ml}) .0 .6 \mathrm{ml}$ hydrogen peroxide solution. After $10 \mathrm{~min}$ Absorbance was measured at $230 \mathrm{~nm}$ against blank solution containing $\mathrm{PO}_{4}$ Buffer without hydrogen peroxide. 
Comparing with standard Statistical analysis: The relative antioxidant activity results were compared using Standard deviation mean and Standard error mean method. P values less than 0.05 were considered as indicative of significance.

\section{RESULT}

There is an increasing evidence that different plant extracts was done according to indigenous antioxidants may be useful in preventing the deleterious consequences of oxidative stress. There is increasing interest in the protective biochemical functions of natural antioxidants contained in spices, herbs and medicinal plants and reducing the risk of degenerative diseases associated with aging.

1. Screening for the preliminary phytoconstituents: Ethanolic extract was evaluated for presence of various phytoconstituents by performing different qualitative chemical tests reported. It showed the presence of flavonoids, anthraquinone/cardiac glycosides, saponins, tannins and phytosterols (Khandelwal; 2003).

2. Screening for Thin Layer Chromatography Giloy Satva The RF value for alkaloids was found to be 0.63 and 0.76 and 0.80 and 0.27 for tannins respectively.

3. Screening for in-vitro Antioxidant models

\section{FOR TRADITIONAL FORMULATION GILOY SATVA}

(Values for all expressed as Mean \pm SEM), ${ }^{*} \mathrm{p}<0.05,{ }^{* *} \mathrm{p}<0.01, * * * \mathrm{p}<0.001$

\section{DPPH (1, 1 diphenyl 2, picryl hydrazyl) Assay}

This is the most widely reported method for screening of antioxidant activity of many plant drugs. DPPH assay method is based on the reduction of methanolic solution of colored free radical DPPH by free radical scavenger. The procedure involves measurement of decrease in absorbance of DPPH at its absorption maxima of $516 \mathrm{~nm}$, which is proportional to concentration of free radical scavenger added to DPPH reagent solution. The activity is expressed as effective concentration $\mathrm{EC}_{50}$. Different concentrations of extract $(50,100,150,200,250 \mu \mathrm{g} / \mathrm{ml})$.

Table.1: DPPH method.

\begin{tabular}{lll}
\hline Sr.no. & Groups & Absorbance $\left(\mathbf{A}^{\mathbf{0}}\right)$ \\
\hline 1 & Standard & $0.694 \pm 0.0023$ \\
2 & $50 \mu \mathrm{g} / \mathrm{ml} \mathrm{HE}$ & $0.448 \pm 0.0030$ \\
3 & $100 \mu \mathrm{g} / \mathrm{ml} \mathrm{HE}$ & $0.440 \pm 0.0030$ \\
4 & $150 \mu \mathrm{g} / \mathrm{ml} \mathrm{HE}$ & $0.386 \pm 0.0010$ \\
5 & $200 \mu \mathrm{g} / \mathrm{ml} \mathrm{HE}$ & $0.216 \pm 0.0040$ \\
6 & $250 \mu \mathrm{g} / \mathrm{ml} \mathrm{HE}$ & $0.159 \pm 0.0011$ \\
\hline
\end{tabular}

Table. 2: Reducing Power Assay.

\begin{tabular}{lll}
\hline Sr.no. & Groups & Absorbance $\left(\mathbf{A}^{\mathbf{0}}\right)$ \\
\hline 1 & Standard & $0.377 \pm 0.0023$ \\
2 & $50 \mu \mathrm{g} / \mathrm{ml} \mathrm{HE}$ & $0.230 \pm 0.0030$ \\
3 & $100 \mu \mathrm{g} / \mathrm{ml} \mathrm{HE}$ & $0.300 \pm 0.0030$ \\
4 & $150 \mu \mathrm{g} / \mathrm{ml} \mathrm{HE}$ & $0.320 \pm 0.0010$ \\
5 & $200 \mu \mathrm{g} / \mathrm{ml} \mathrm{HE}$ & $0.400 \pm 0.0040$ \\
6 & $250 \mu \mathrm{g} / \mathrm{ml} \mathrm{HE}$ & $0.480 \pm 0.0011$ \\
\hline
\end{tabular}

\section{Determination of reducing power}

This method is based on the principle of increase in the absorbance of the reaction mixture. Increase in the absorbance indicates increase in the antioxidant activity. In this method antioxidant compound forms a colored complex with potassium ferricyanide, trichloro acetic acid and ferric chloride, which is measured at $700 \mathrm{~nm}$.

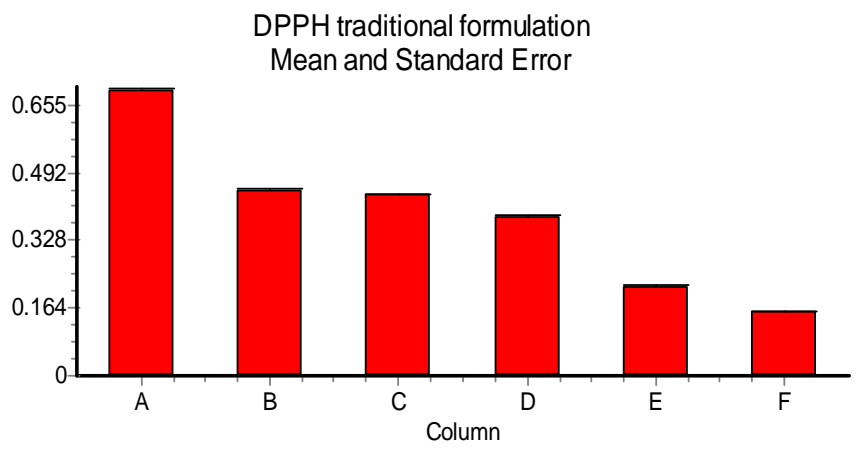

Fig. 1: DPPH Method SEM

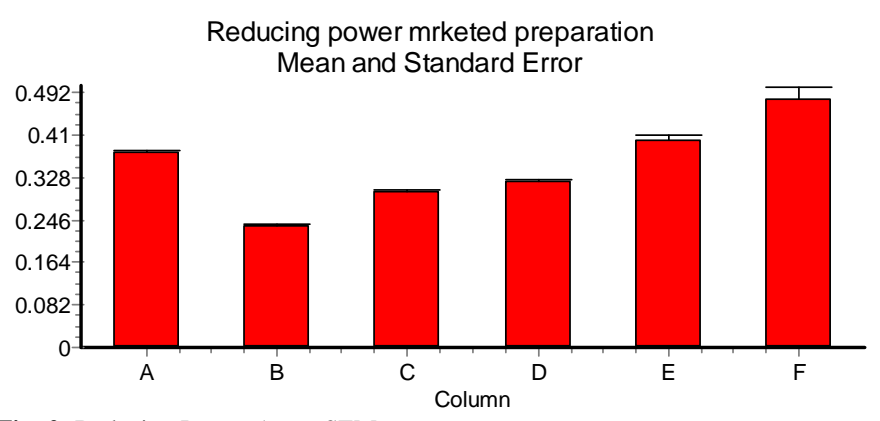

Fig. 2: Reducing Power Assay SEM

\section{Hydrogen peroxide scavenging activity}

Table. 3:Hydrogen Peroxide Scavenging Assay.

\begin{tabular}{lll}
\hline Sr.no. & Groups & Absorbance $\left(\mathbf{A}^{\mathbf{0}}\right)$ \\
\hline 1 & Standard & \\
2 & $50 \mu \mathrm{g} / \mathrm{ml} \mathrm{HE}$ & $1.125 \pm 0.0030$ \\
3 & $100 \mu \mathrm{g} / \mathrm{ml} \mathrm{HE}$ & $1.122 \pm 0.0030$ \\
4 & $150 \mu \mathrm{g} / \mathrm{ml} \mathrm{HE}$ & $1.143 \pm 0.0010$ \\
5 & $200 \mu \mathrm{g} / \mathrm{ml} \mathrm{HE}$ & $1.153 \pm 0.0040$ \\
6 & $250 \mu \mathrm{g} / \mathrm{ml} \mathrm{HE}$ & $1.162 \pm 0.0011$ \\
\hline
\end{tabular}

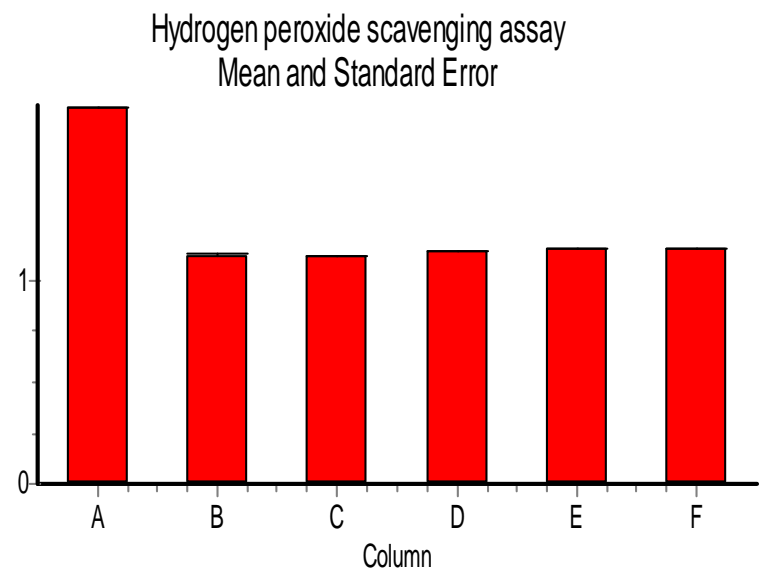

Fig. 3: Hydrogen Peroxide Scavenging Assay SEM . 
FOR HYDROALCOHOLIC EXTRACT OF C.ORCHIOIDES GAERTN.
(Values
for
all
expressed

Mean \pm SEM), ${ }^{*} \mathrm{p}<0.05,{ }^{* *} \mathrm{p}<0.01, * * * \mathrm{p}<0.001$

\section{DPPH Assay}

Table. 4: DPPH Assay

\begin{tabular}{ccc}
\hline Sr.no. & Groups & Absorbance $\left(\mathbf{A}^{\mathbf{0}}\right)$ \\
\hline 1 & Standard & $0.694 \pm 0.0023$ \\
2 & $50 \mu \mathrm{g} / \mathrm{ml} \mathrm{HE}$ & $0.462 \pm 0.0030$ \\
3 & $100 \mu \mathrm{g} / \mathrm{ml} \mathrm{HE}$ & $0.440 \pm 0.0030$ \\
4 & $150 \mu \mathrm{g} / \mathrm{ml} \mathrm{HE}$ & $0.296 \pm 0.0010$ \\
5 & $200 \mu \mathrm{g} / \mathrm{ml} \mathrm{HE}$ & $0.216 \pm 0.0040$ \\
6 & $250 \mu \mathrm{g} / \mathrm{ml} \mathrm{HE}$ & $0.150 \pm 0.0011$ \\
\hline
\end{tabular}

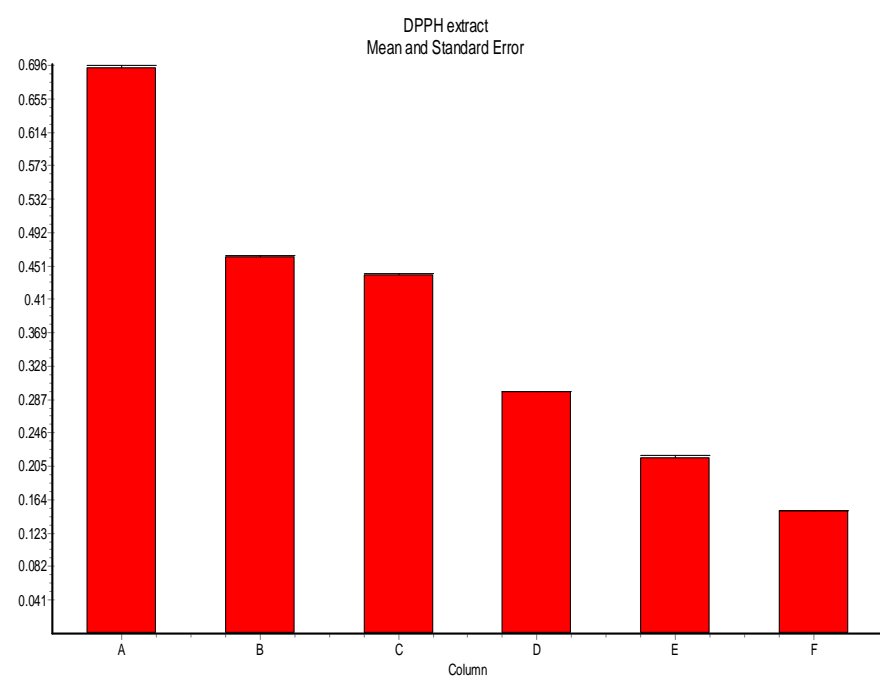

Fig. 4: DPPH Method Mean \pm SEM

Table. 5: Determination of reducing power

\begin{tabular}{ccc}
\hline Sr.no. & Groups & Absorbance $\left(\mathbf{A}^{\mathbf{0}}\right)$ \\
\hline 1 & Standard & $0.377 \pm 0.003$ \\
2 & $50 \mu \mathrm{g} / \mathrm{ml} \mathrm{HE}$ & $0.111 \pm 0.001$ \\
3 & $100 \mu \mathrm{g} / \mathrm{ml} \mathrm{HE}$ & $0.142 \pm 0.002$ \\
4 & $150 \mu \mathrm{g} / \mathrm{ml} \mathrm{HE}$ & $0.237 \pm 0.004$ \\
5 & $200 \mu \mathrm{g} / \mathrm{ml} \mathrm{HE}$ & $0.322 \pm 0.007$ \\
6 & $250 \mu \mathrm{g} / \mathrm{ml} \mathrm{HE}$ & $0.466 \pm 0.003$ \\
\hline
\end{tabular}

Reducing power extract

Mean and Standard Error

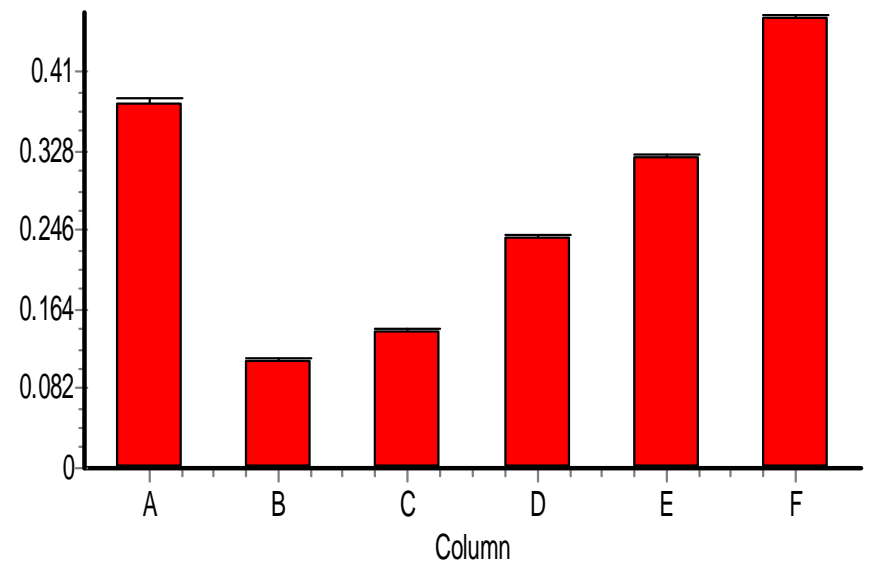

Fig. 5: Reducing Power Assay SEM.
HYDROGEN PEROXIDE SCAVENGING ASSAY

Table. 6: Hydrogen Peroxide Scavenging Assay.

\begin{tabular}{ccc}
\hline Sr.no. & Groups & Absorbance $\left(\mathbf{A}^{\mathbf{0}}\right)$ \\
\hline 1 & Standard & $1.852 \pm 0.001$ \\
2 & $50 \mu \mathrm{g} / \mathrm{ml} \mathrm{HE}$ & $0.596 \pm 0.0005$ \\
3 & $100 \mu \mathrm{g} / \mathrm{ml} \mathrm{HE}$ & $1.350 \pm 0.0011$ \\
4 & $150 \mu \mathrm{g} / \mathrm{ml} \mathrm{HE}$ & $1.482 \pm 0.0023$ \\
5 & $200 \mu \mathrm{g} / \mathrm{ml} \mathrm{HE}$ & $1.589 \pm 0.0005$ \\
6 & $250 \mu \mathrm{g} / \mathrm{ml} \mathrm{HE}$ & $1.895 \pm 0.0017$ \\
\hline
\end{tabular}

h202

Mean and Standard Error

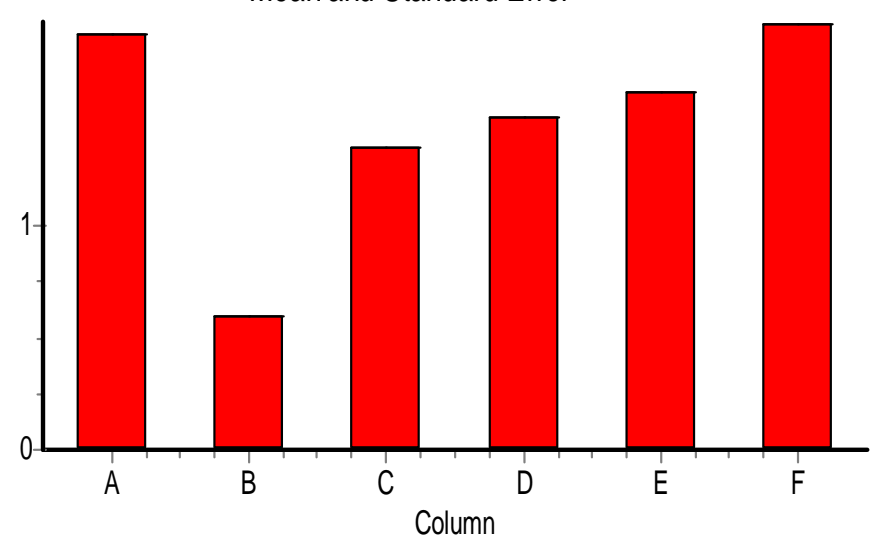

Fig. 6: Hydrogen Peroxide Scavenging Assay SEM

\section{DISCUSSION}

The results revealed that the extract shows potent scavenging activity when compared with standard Butylated hydroxy toluene. The plant extracts further studied for the phytochemical screening and thin layer chromatographic analysis with various solvent systems. It contains Flavonoids, glycosides, saponins and some amount of phytosterols. These active constituents alone or in combination may be responsible for the observed antioxidant activity. Further study on the active components and the mutual effect of these plant extract machinery may provide a better understanding about plant with a goal of elucidating their active potential compounds.

\section{REFERENCES}

Adailkan PG., Gauthaman K. History of herbal medicines with an insight on the pharmacological properties of Tribulus terrestris. The Aging Male. 2001; 4:163-169.

Ashok KJ. Imbalance in antioxidant defence and human diseases: Multiple approach of natural antioxidant therapy. Current Science. 2001; 11: 1179-1186.

Babu BH., Shylesh BS., Padikkala J. Antioxidant and hepatoprotective effect of Alanthus icicifocus. Flitoterapia. 2001; 72: 272277.

Beris H. Antioxidant effects a basis of drug selection. Indian Drugs. 1991;42: 569-605.

Campbell IC., Abdula EM. Stratergic approaches to in vitro neurotoxicology. Approaches and methods. Neurotoxicology. 1995; 495497.

Chauhan NS, Dixit VK. Spermatogenesis activity of rhizomes of Curculigo orchioides Gaertn on male rats. Int J Appl Res Nat Prod. 2008; 1(2): 26-31.

Chauhan NS, Rao CV, Dixit VK. Effect of Curculigo orchioides rhizomes on sexual behaviour of male rats. Fitoterapia. 2007; 78(78): 530534. 
Chauhan NS., Dixit VK. Antihyperglycemic activity of the ethanolic extract of Curculigo orchioides Gaertn. Pharmacog Mag. 2007; 3(12): 236-239.

Cotran RS. Kumar V and Collins T. Robbin's pathological basis of diseases. $6^{\text {th }}$ ed. Thomsan Press, Noida, India (1999) 111

Dapeng C., Zheng YM., Ting H. Curculigo chemical constituents and biological activities of Progress. J Pharmaceutical Care and Research. 2008; 8 (1): 5963.

David GB., Erik EA., Rohini S., Alfins. Antioxidant enzyme expression and ROS damage in prostatic intraepithelial neoplasia and cancer. Cancer. 2001; 89: 124-134.

Govindarajan R., Vijayakumar M., Pushpangadan P. Antioxidant approach to disease management and the role of 'Rasayana' herbs of Ayurveda. J Ethnopharmacol. 2005; 99(2): 165-178.

Halliwell B., Gutteridge JM. Free radicals in biology and medicine, $2^{\text {nd }}$ ed. Clarendon Press, Oxford (1998) 10.

Hye Rhi Choiet al. (2002).Peroxynitrite Scavenging Activity of Herb extracts, Phytother. Res., 16, p 364-367.

Jacob V., Michael A. Nutritional antioxidants: mechanism of action, analyses of activities. Nutrition. 1999; 49:1-7.

Jaiswal S., Batra A., Mehta BK. The antimicrobial efficiency of root oil against human pathogenic bacteria and phytopathogenic fungi. J Phytopathol. 1984; 10: 230-234.
Jayaprakash GK., Singh RP., Sakariah KK. Antioxidant activity of grape seed extracts on peroxidation models. J.Agric Food Chem. 2001; 55:1018-1022.

Kanner J. Natural antioxidants in grapes and wines. J. Agric. Food. Chem. 1994; 42: 64-69.

Khandelwal KR. A textbook of practical Pharmacognosy, $16^{\text {th }}$ ed. Nirali Prakashan, Pune. (2003) 149-153.

Marx JL., Oxygen free radicals linked to many diseases. Science. 1987; 235:529-531.

Navarro MC. Free radical scavenger and anti hepatotoxic activity of rosmarinus tomentosus. Plantamedica. 1993; 59:312-314.

Pandit P., Singh A., Bafna AR., Kadam PV., Patil MJ. Evaluation of antiasthmatic activity of Curculigo orchioides Gaertn. rhizomes. Indian J Pharm Sci. 2008; 70 (4): 440-444.

Puri HS. Rasayana ayurvedic herbs for longevity and rejuvenation.2003; 2 : 209-211.

Rao KS., Mishra SH. Effect of rhizomes of Curculigo orchioides Gaertn. on drug induced hepatoxicity. Indian Drugs. 1996; 33(9): 458-461.

Robak J., Gryglewski RJ. Flavonoids are scavengers of superoxide anions. Biochem. Pharmcol. 1998; 37:837-841.

Said HK. Traditional medicine in the service of health. $2^{\text {nd }}$ ed. Hamadard foundation press, Karachi. (2005) 79-86. 